\title{
Determinants of Child Height and Weight in Cambodia: A Quantile Regression Analysis
}

Kana Miwa (Kushiro Public University of Economics)

\author{
カンボジアにおける子どもの身長・体重の決定要因 \\ 一分位点回帰分析より一
}

\section{三輪 加奈 (釧路公立大学)}

\begin{abstract}
本稿の目的は, 開発途上国のひとつであるカ ンボジアの 5 歳未満の子どもの身長と体重で測っ た栄養状態の決定要因について, カンボジア社 会経済調査 (CSES) 2009 からのデータを用いて, 分位点回帰分析の手法により検証することであ る. 子どもの栄養状態は，その分布の位置によ り決定要因括よびその影響が異なるものと考兄 られるが，多くの既往研究が用いている OLSな ぞの標準的な分析手法では，その違いについて は考慮しきれない。そこで, CSES 2009 のデー
\end{abstract}

\section{Introduction}

Improving child health and reducing child malnutrition are key tasks for developing countries, where poverty and child malnutrition are highly correlated. An investigation into the determinants of childhood malnutrition provides an analytical basis for important clues to the improvement of child nutrition and reduction of poverty in those struggling countries.

Studies in this area have shown that nutrition status in childhood is determined by various household and parental characteristics, such as parental education, socioeconomic status, nourishment and health awareness, household income, (food) consumption, and growth in household income. In addition, the characteristics of the residential locality, for example, easy access to health and sanitation facilities and health-care services, have a significant impact on child health. The child's characteristics such as sex, birth weight, birth order, number of siblings, and health-related shock (illness) also affect nutrition status in childhood.

Previous studies have typically estimated the determi-

\begin{abstract}
タを用いて，分位点回帰分析を行らことで，こ れまで同手法を用いた実証分析がなされていな いカンボジアに拈いて，5歳未満児の栄養状態の 決定要因に関する新たな知見を提示することが 可能となると考元る。実証分析の結果，家計の 食料消費・保有資産, 父親の教育, 衛生施設や 食料不足の有無などの変数について，それらの 影響が栄養状態の分布の位置によりそれぞれ異 なるといら結論が得られた。
\end{abstract}

nants of child nutrition-household, community (residential environment), and/or child-related variables - for the average child, primarily using the ordinary least squares (OLS) method. However, it is argued that these socioeconomic variables may affect child nutrition in different ways at different points of the conditional nutritional distribution. Therefore considering only the conditional mean of the entire distribution of child nutrition can yield misleading results.

To address this, Borooah [3], Bassolé [2], Aturupane et al. [1], and Fenske et al. [4] estimated the determinants of nutritional status for children using quantile regressions, which analyze different parts of the distribution of child nutritional outcomes. Those studies validated the quantile regression results and showed that the determinant variables have different effects at different quantiles of the distribution. Therefore, it may be more meaningful to investigate the determinants of child anthropometry at each quantile of the child's height and weight distributions, considering the fact that the policy objective is to improve the nutritional status of malnourished children. 
There is no Cambodia case study about the determinants of child health analyzed by the quantile regression, as far as we know. Thus, in this study, we explore the effects of determinant variables on the nutritional status (as measured by height-for-age and weight-for-age z-scores) of Cambodian children under five years of age, using quantile regression analysis, based on data from the Cambodia Socio-Economic Survey (CSES) 2009.

\section{Data}

In our analysis, we use data from Cambodia SocioEconomic Survey 2009. CSES 2009 was conducted by Cambodia National Institute of Statistics (NIS) of the Ministry of Planning.

CSES 2009 was conducted among a nation- wide representative sample of 12,000 households.

The household questionnaire contained questions on the education and economic activity (work) of each household member, household income and expenditure (food and nonfood consumption), agricultural activity, vulnerability, and housing conditions. Housing conditions include information on drinking water and sanitation (toilet facility).

CSES 2009 also provides anthropometric data for 5,617 children 0-59 months (under 5 years) of age, as well as information on the health of children. This sample is used because we analyze the nutritional status of children based on their height-for-age and weight-for-age measurements.

\section{Child Nutrition in Cambodia}

To evaluate child nutritional outcomes, we use two anthropometric measures in this paper: height-for-age and weight-for-age scores. A child's height-for-age and weightfor-age $\mathrm{z}$-scores are good indicators of his/her nutritional status (see WHO [5] and the Centers for Disease Control and Prevention website for more details).

Children whose height-for-age $z$-score (HAZ) is below -2 standard deviations from the mean of the reference population are considered (moderately or severely) stunted and are chronically malnourished. Children whose weightfor-age $z$-score (WAZ) is below -2 are classified as underweight. Children whose height-for-age/weight-for-age score is below -3 are considered severely stunted/underweight.

In this study, we exclude children with height-for-age and weight-for-age $z$-scores of less than -6 or greater than 6 because of probable errors in either height/weight or age data, and use 4,948 children under 5 years (60 months) of age from the CSES 2009 data.
The CSES 2009 data indicate that the average HAZ is -1.640 and the average WAZ is -1.558 . About $42.3 \%$ of Cambodian children under five are stunted and $22.4 \%$ are severely stunted; $38.3 \%$ are underweight and $16.8 \%$ severely underweight. These findings imply that children in Cambodia suffer from long-term chronic under-nutrition, reflected in high rates of stunting, as well as short-term acute malnutrition, manifested in low weight-for-age scores.

\section{Empirical Model}

We will consider the determinant function of child height and weight as follows:

$$
H_{i}=\beta_{0}+\boldsymbol{\beta}_{1}^{\prime} \cdot \mathbf{X}_{i}+\boldsymbol{\beta}_{2}^{\prime} \cdot \mathbf{X}_{h}+\beta_{3} \cdot V_{h}+u_{i}
$$

The dependent variables $\left(H_{i}\right)$ are the children's anthropometric measures: height-for-age and weight-for-age z-scores.

The independent variables include the child's characteristics $\left(\mathbf{X}_{i}\right)$ such as sex, age, and birth order. Age is represented by dummy variables for six discrete age categories: $0-5,6-11,12-23,24-35,36-47$, and 48-59 months, with $0-5$ as the base group. $\mathbf{X}_{h}$ represents the household-level variables: the household head's sex (1 if female), age (in years), and spoken language (1 if household head does not speak Khmer, the national language of Cambodia), log of household food consumption (in the past 7 days) and $\log$ of assets (total value of durable goods), mother's and father's educational background (years of education), and whether the child has a mother or father in the household (dummy variables).

In developing countries, unsafe water and poor sanitation are considered as the cause of the burden of diseases, especially diarrheal diseases. Thus, we will consider the impact of the safe drinking water source (1 if household uses piped water) and flush toilet facility (1 if household has flush toilet at home). Food shortage dummy (1 if household has not had enough food in the last 12 months) is also included. $V_{i}$ is rural dummy.

In this paper, we will estimate equation (1) at different points of the dependent variable's conditional distribution, using a quantile regressions technique. Quantile regressions are estimated for the median and the quintiles (20, 40,60 , and 80 percentile) of child height and weight with 100 repetitions.

During empirical analysis of the determinants of child nutritional status, an issue associated with household- 
level clustering occurs if a household has multiple children in the sample age range (age $0-59$ months). To avoid this, we will use bootstrapped standard error estimation at the household-level cluster.

\section{Estimation Results}

Quantile regression estimates of child height are presented in the left column and those of child weight in the right column of Table 1. For comparison, we also report the OLS estimation results in the table.

\section{(1) Height-for-age z-score (HAZ)}

Consider height results first. OLS estimation results indicate a gender effect and strong age effects-HAZ declining with age. Among the household-level variables, the coefficients of household head age, food consumption, household assets, father's education (but not mother's), and flush toilet at home are positive and significantly different from zero.

From the quantile regression results for child height, we find a significant gender effect at the 0.20 to 0.60 quantiles of height; girls have an advantage over boys for long-term nutritional status. This result is indicative of intra-household gender differences at some of the quantiles. Age dummy coefficients at the higher end of the distribution are large, significant, and negative; however, they are insignificant at the 0.20 quantile. One possible reason for this is that children with short height in early childhood will continue to stay shorter and not change nutritional status much.

For household-level variables, the higher the household head's age, the higher the child's HAZ at the 0.20 to 0.60 quantiles. The level of food consumption per capita has a significant impact on height at the 0.40 to 0.80 quantiles; in this range, a $1 \%$ higher food consumption leads to an $\mathrm{HAZ}$ increase from 0.149 to 0.237 . The coefficients of household assets have a positive sign and are significant at the $0.20,0.40$, and 0.50 quantiles. These indicate that food consumption has a strong effect on child height at the higher ranges of the conditional distribution, while the level of asset holdings has a strong effect at the lower ranges.

As regards parents' years of schooling, the coefficient of father's education is significant at the middle quantiles (0.40 to 0.60); however, mother's education has no significant effect on child height at any of the quantiles. This suggests that, in the middle of the conditional distribution of height, father's education is an important determinant of child height in Cambodia.

Children living in homes without a mother have significantly lower height $z$-scores in the higher quantiles $(0.60$ and 0.80 ), with coefficients between -0.395 and -0.494 .

At the low-end quantiles, usage of piped water significantly increases HAZ. Having flush toilet at home has a significantly positive effect on height at the 0.60 and 0.80 quantiles; availability of flush toilet has a greater effect at the upper than the lower quantiles. At the same quantiles, food shortage has a significantly negative impact on the long-term nutritional status. This suggests that even though children have a better nutritional status, measured by height, they do face malnutrition risk from food shortage.

\section{(2) Weight-for-age z-score (WAZ)}

Next, we consider the weight results. From the OLS estimation results, we find that the age of the child, food consumption, household assets, and father's education have significant effects on weight; these are similar to the height results. In addition, the OLS estimation of the child's WAZ reported that the coefficients of dummy variables for non-Khmer speakers and rural area are significant and negative.

In the quantile regression results for weight, all child age dummies have a negative sign and are statistically significant at all quantiles. This suggests that child age has a strong effect on weight, with large coefficients at the top end of the distribution.

With respect to household head variables, children with a female household head have significantly lower weight $z$-scores at the 0.60 quantile; the household head's gender effect is serious at that quantile. Being a non-Khmer speaker is strongly and negatively related to child weight at the $0.20,0.50$, and 0.60 quantiles.

We also found that the level of food consumption is significant at the $0.20,0.50$, and 0.60 quantiles; the highest quantile (0.80) showed no evidence of consumption effect. Unlike the HAZ results, the per capita food consumption effect on the short-term nutritional status might be greater at the lower quantiles, with a large coefficient at the 0.20 quantile. At the middle quantiles $(0.40,0.50$, and 0.60$)$, the coefficients of household assets are significant and positive.

Consider the parental schooling; the father's years of schooling has a positive and significant effect on child weight at the 0.40 and 0.60 quantiles. At the low-end quantiles, the mother's absence from the household has a positive effect on child weight. This result indicates the possi- 


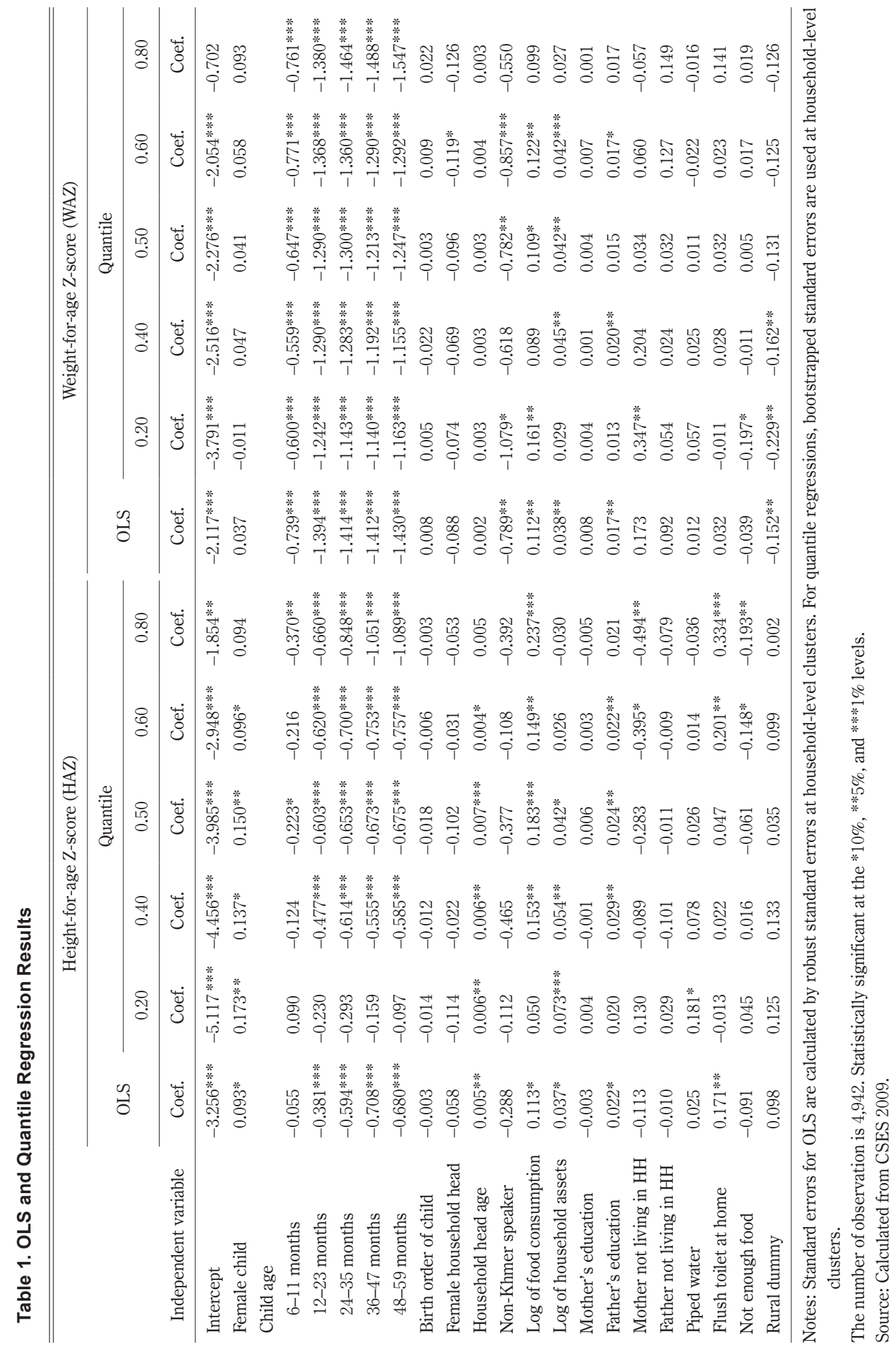


Table 2. Test of Equality of Coefficients between Quantiles (all slope coefficients)

\begin{tabular}{cccccc}
\hline \hline \multirow{2}{*}{$\begin{array}{c}\text { Null } \\
\text { Hypothesis }\end{array}$} & \multicolumn{2}{c}{ HAZ } & & \multicolumn{2}{c}{ WAZ } \\
\cline { 2 - 3 } \cline { 5 - 6 } & $F(20,4921)$ & Prob. & & $F(20,4921)$ & Prob. \\
\hline Q20=Q40 & 2.04 & 0.00 & & 1.40 & 0.11 \\
Q20=Q50 & 2.25 & 0.00 & & 1.21 & 0.23 \\
Q20=Q60 & 2.09 & 0.00 & & 1.41 & 0.11 \\
Q20=Q80 & 3.60 & 0.00 & & 2.47 & 0.00 \\
Q40=Q50 & 0.88 & 0.62 & & 0.71 & 0.82 \\
Q40=Q60 & 1.26 & 0.19 & & 0.74 & 0.79 \\
Q40=Q80 & 2.46 & 0.00 & & 1.97 & 0.01 \\
Q50=Q60 & 1.21 & 0.24 & & 0.46 & 0.98 \\
Q50=Q80 & 2.30 & 0.00 & & 1.09 & 0.36 \\
Q60=Q80 & 1.68 & 0.03 & & 1.54 & 0.06 \\
\hline
\end{tabular}

Joint test of equality of all slopes coefficients

$\begin{array}{lllll}\mathrm{F}(80,4921) & 5.26 & 0.00 & 4.99 & 0.00\end{array}$

Note: Test results of equality of coefficients for each variable are available upon request.

bility that the child's mother is working away from home and sends some money, so the household has sufficient food to eat and to provide for child, at least in the short run.

The coefficients of the dummy variable for not having enough food are negative and significant only at the 0.20 quantile. This suggests that the effects of food shortage on weight (short-term nutritional status) are greater at the lower conditional distribution of weight.

The results also show the residential locality effect on short-term nutritional status; children living in rural areas have significantly lower $z$-scores for weight, compared to those living in an urban area, at the 0.20 and 0.40 quantiles.

It is imperative to test whether the quantiles are statistically different from each other after obtaining quantile regression estimates. Table 2 presents the results of the test of equality of coefficients, using an F-test. The null hypothesis that the coefficient vectors are the same for the different quantiles equation is rejected in some of pairwise comparisons and jointly. The 0.20 quantile versus the 0.80 quantile, the 0.40 quantile versus the 0.80 quantile, and the 0.60 versus 0.80 quantile were observed to have estimates significantly different from each other both in HAZ and WAZ analyses. The results suggested that there is a significant difference in the magnitude of the impact of the determinants of child malnutrition between the lower and upper quantiles.

\section{Conclusion}

In this paper, we explored the effects of determinant variables on the nutritional status (as measured by heightfor-age and weight-for-age $z$-scores) of Cambodian children under five years of age. From the estimation results, based on quantile regressions, we found that the determinants of child nutrition do not have the same effect at different points of the conditional distributions of height and weight; OLS estimates are inadequate to show these effects.

Quantile regressions show that some of the explanatory variables considered in this paper tend to have a greater and more significant effect on child height and weight at the higher than the lower quantiles. For instance, parental (especially the father's) education and availability of a flush toilet have a greater effect on child height and weight at the middle or upper quantiles than at the lower. In addition, for HAZ, the coefficient of food consumption has no significant effect at the low-end quantile. This suggests that temporality increase of consumption is not enough to improve child's malnutrition status for long-term.

The policy implication is that, since these general interventions are not as effective in raising the nutritional status of children at the lower tail of the conditional height and/or weight distributions, it may be important to introduce direct nutritional interventions, such as food supplementation programs, for at-risk children. Furthermore, in order to strengthen and improve child nutrition status and to reach each child, particularly children with severe and acute malnutrition, a more stable and reliable programs are necessary.

\section{References}

[1] Aturupane, H., Deolalikar, A. B., and Gunewardena, D., "The Determinants of Child Weight and Height in Sri Lanka," UNU-WIDER Research Paper, No. 2008/53, 2008.

[2] Bassolé, L., "Child Malnutrition in Senegal: Does Access to Public Infrastructure Really Matter? A Quantile Regression Analysis,” Jobmarket Paper, CERDI-CNRS, University of Auvergne, 2007.

[3] Borooah, V. K., "The Height-for-age in Indian Children," Economics and Human Biology, Vol. 3, No. 1, 2005, pp. 45-65.

[4] Fenske, N. Kneib, T., and Hothorn, T., "Identifying Risk Factors for Severe Childhood Malnutrition by Boosting Additive Quantile Regression,” Journal 
of the American Statistical Association, Vol. 106, No. 494, 2011, pp. 494-510.

[5] World Health Organization (WHO), WHO Child Growth Standards: Growth Velocity Based on
Weight, Length and Head Circumference; Methods and Development, 2009.

(受理日：2013 年 3 月 4 日) 